This document is a draft version of the paper: Akhavan M., Ghiara H., Mariotti I., Sillig C. (2020), Logistics Global Network Connectivity and its determinants. A European City Network Analysis, Journal of Transport Geography 82, https://doi.org/10.1016/i.jtrangeo.2019.102624

\title{
Logistics Global Network Connectivity and its determinants. A European City Network Analysis
}

\author{
Mina Akhavan ${ }^{a}$, Hilda Ghiara ${ }^{b}$, Ilaria Mariotti ${ }^{a}$, Cécile Sillig ${ }^{b}$ \\ ${ }^{\text {a }}$ Department of Architecture and Urban Studies, Polytechnic of Milan, Italy \\ ${ }^{\mathrm{b}}$ Department of economics, University of Genoa, Italy
}

\begin{abstract}
The Globalization and World City Research Network classifies global cities according to their connectivity through advanced producer service activities. Recent studies have suggested there is scope to develop a new classification of cities based on advanced logistics services. Within this framework, the aim of this paper is twofold: (i) to develop an interlocking Logistics Global Network for advanced logistics in Europe and measure the Logistics Global Network Connectivity (LGNC) of the host cities; (ii) to explore the variables explaining each the cities' score on the LGNC. The aim is achieved by means of a mixed methodological approach based on Taylor's Interlocking Network Model and via econometric analysis through Ordinary Least Square regression (OLS).
\end{abstract}

\section{Key Words}

Advanced Logistics Service, Global Cities, World City Network, Logistics Global Network Connectivity, Europe, Third-Party Logistics (3PL)

\section{Introduction}

The studies on the World City Network (WCN) have mainly focused on Advanced Producer Services (APS) serving large global firms (Sassen, 1991; Taylor, 2001). The APS are defined as activities with high addedvalue for local and regional economies, which are the distinctive features of the world city formation, such as finance, insurance, real estate, accountancy, law, advertisement, management and consultancy (Sassen, 1991; Beaverstock et al., 1999). More specifically, the Globalization and World City Research Network (GaWC) inventory classifies global cities into four groups (Alpha, Beta, Gamma and Sufficiency) according to their connectivity with one another through the APS activity. Recent papers have suggested this approach could be applied to advanced logistics services (Antoine et al., 2017; O'Connor, 2010; O'Connor et al., 2012, 2016; Wang and Cheng, 2010), which play a prominent role in the management of both physical and information flows of the global economy (Hesse and Rodrigue, 2006; Jacobs et al., 2010). 
During the last decade, as a consequence of the globalization of production, the activities of logistics operators have evolved (Norall, 2013). Particularly, the third-party logistics firms (labelled 3PL), which currently dominate the industry, used to be simple carriers serving local markets. Some of these firms evolved - through a process of industrial concentration (Van Den Heuvel et al., 2013)- towards more complex service providers at the global scale, which makes them an essential service provider ( $O^{\prime}$ Connor, 2016). The 3PL firm's services are carried out by an external company on behalf of a shipper (or client) and manage multiple logistics tasks. These activities are mainly offered in an integrated way; the cooperation between the shipper and the external company is an intended to be a long-term contractual relationship (lasting for at least one year) (European Commission, 2000). The 3PL firm undertakes: (i) management, analytical and design activities associated with transport and warehousing (e.g. inventory management, information related activities, including tracking and tracing), (ii) the value-added activities involving the organization of secondary assembly of products, and (iii) overall supply chain management (Laarhoven et al., 2000). Although there is a rather extensive literature on the physical traffic flows and the location of logistics facilities (Graham \& Sahling, 2004; Hesse, 2008, 2013; Hall \& Hesse, 2013; Hesse \& Rodrigue, 2004), studies of the location of these information- intensive services are limited, especially investigations into the part that cities within the WCN play in their distribution across the globe.

Within this theoretical framework, the current paper is directed towards a two aims: (i) to develop and analyze an interlocking network model dedicated to advanced logistics firms in Europe, including the high value-added activities carried out by 3PL firms, and labelled Logistics Global Network Connectivity, and measure the connectivity of host cities to this network ; (ii) to investigate the determinants of each cities' LGNC score. To address these aims, the I study has applied the Taylor's Interlocking Network methodology to identify the network and used econometric analysis (OLS) to explore host city activity. The study focuses on Europe (UE plus Schengen) and is based on the exploration of the locational patterns of 27 global 3PL firms that operate 722 offices in Europe. The interpretation of the analysis with respect to the cities pays particular attention to the location patterns of the transport and logistics industry. More specifically, the analysis explores whether advanced logistics firms follow traffic flows or whether they are mainly attracted to knowledge-intensive urban contexts.

In particular the research investigates the influence of cities which host important transport infrastructures (i.e. ports and airports) in comparison to those with a broader base of advanced services which is typical of world cities.

The remainder of this paper is organized as follows. The next section presents a review of the main studies concerning transport and logistics within the WCN literature, and the conception of advanced logistics as APS is argued accordingly. Section 3 explains in length the data collection used to build the interlocking network model. Furthermore, this section elaborates the methodology, presents the econometric analysis and discusses its main outcomes. Section 4 develops the empirical analysis on the determinants of city results on European Logistics Global Network Connectivity (LGNC). The final section concludes by highlighting the main findings followed by policy implications that bring the paper to a close.

\section{Theoretical Background: World City Networks and Advanced Producer Services}

Following the pioneering works by Sassen (1991) and Taylor (2004) on global/world cities, the WCN approach was widely used to study the intra-firm networks of advanced producer services in different urban nodes. Researchers have nevertheless encountered difficulties in developing appropriate methodologies to empirically describe the World City Network (Derudder et al, 2007; Taylor, 2001). In the early 2000s, Peter J. Taylor and the Globalization and World Cities (GaWC) research network, at the University of Loughborough in UK, developed an original methodology to address this problem which gained an extensive approval from the scientific community. The basic methodology uses the websites of the APS companies as a data source and interprets the relationship between cities as an expression of intra-firm networks - i.e. relations between offices of the same firm located in different cities - 
(Beaverstock et al., 1999; Taylor, 2001). The most referenced WCN study ${ }^{1}$, which has been repeated over the years to highlight the dynamic nature of the network, analyses the presence of about one hundred global companies within finance, accountancy, advertising, law, management consultancy sectors in about 300 cities worldwide. The network is mainly described through the cities' level of connectivity (ranking of most connected cities), and a relational matrix between pairs of cities. A city nodal connection value is de facto related to the following factors: a) number of firms; b) importance of local offices (service value); c) offices belonging to companies with a large network. The relationship between pairs of cities depends on the presence of a similar mix of companies (present in both cities) and the importance of local offices.

In addition to the above-mentioned attributes, the WCN research extends to other services and industries characterized by similarities to the APS as functions, exploring locational behavior and inter-sectorial relations (Growe \& Blotevogel, 2011; Lüthi et al., 2010, 2018; Pain \& Hall, 2006). Moreover, while the main APS generally serve a wide range of customers, some studies have focused on companies, or business divisions, mainly dedicated to specific sectors (e.g. see law firms specialized in maritime law in Jacobs et al., 2010).

Within the transport sector, the most developed literature concerns the port industry and maritime sector. One of the major contributions to the topic has been written by Verhetsel and Sel (2009) who explored the port-city network based on the GaWC methods, focused upon the location of container shipping companies, container terminal operators, and their extent of linkage. Their study highlights that several world cities have also a maritime focus and identified the following most important world maritime cities: Hong Kong, Hamburg, Singapore, Shanghai, Tokyo, New Jersey/New York, Bangkok/Laem Chabang and London. According to this network analysis, only Hong Kong, Hamburg and New York are the leading service nodes within the world maritime city network.

Other studies (see, for example, Jacobs et al., 2010, 2011) have focused on the maritime APS firms (i.e. maritime law, P\&I clubs, insurance brokers, classification societies, consultancy, surveyors and maritime organizations). Their findings underline that in the case of maritime APS, firm location is mainly linked to the presence of a port industry and other maritime APS firms, rather than to the mere presence of commodity flows. In other words, maritime APS tend to locate in a knowledge-intensive context, either specialized in transport infrastructures (e.g. port cities) or in world cities. However, the research suggested that urbanization economies are considered less important for the maritime APS than for other APS.

While in the studies described above, the maritime and port industries were considered as non-APS dominant players (Verhetsel and Sel, 2009) or specialized companies/divisions of the "classic" main APS (Jacobs et al., 2010, 2011), recent studies have focused on the logistics sector specifically (Antoine et al., 2017; O'Connor et al., 2016) providing a sharper focus upon logistics within the broader definition of APS. That focus emerges as the activities carried out by the logistics operators (3PL firms) are a special part of APS. Global 3PL offer a very broad panel of services and are highly integrated with their customers (Saglietto, 2013) and they manage the supply chain for their customers, through the establishment of terms and timing of distribution and also production (Rodrigue, 2006). This role makes the logistics operator an essential service provider for global manufacturers, while also drawing upon highly specialized expertise and high-level managerial skills from other APS providers. As O'Connor et al. (2016, p. 483) have emphasized, "logistics services are also part of a 'service world' as they cannot operate without integration with other services, especially information technology, finance, marketing, and government services".

It has to be recognized that 3PL firms that operate across the global market have fundamental characteristics that distinguish them from "traditional" APS: they own part of the transportation infrastructure and facilities they use, and also part of the functions they perform as transportation and storage that are purely operational and unspecialized. So, a specificity of the 3PL logistics sector is that it includes both material/operational activities and high-value informational activities, which are characterized by differences in terms of value and geographical organization (Hall et al. 2011). This internal duality represents an important constraint in the application of WCN-related research approaches to logistics. In fact, while there is extensive literature on traffic flows and location of logistics facilities in 
general, studies about the locational behavior of knowledge-intensive logistics, as well as those regarding logistics within the WCN framework, are relatively less developed or incomplete because of the complexity created by the mix of high-skilled/management functions and operational/unspecialized functions.

O'Connor, along with other scholars, has developed most of the existing research on the relation between logistics industry and World Cities. A first study (O'Connor, 2010), based on the analysis of port and airport traffic flows, highlights that about two-thirds of port and airport cargo traffic passes from terminals located in close proximity to 73 World Cities. Nevertheless, the study does not provide specific evidence on advanced logistics activity. Another study by O'Connor et al. (2012) focuses on the locational behavior of advanced logistics services and transport management. The analysis is based on limited census data in 2008 and is applied to the US context. The results show that the location of the advanced logistics activities in a city presents a correlation to both the city's employment in transportation and warehousing, and to the degree of specialization in APS. Finally, a recent contribution (O'Connor et al., 2016) analyses the location pattern of 60 top global $3 \mathrm{PL}^{3}$ and their global and regional headquarters. The authors highlight that, at least for regional headquarters, 3PL seem to prefer world cities to large transportation centers, while global headquarters often remain where the firm was born.

Therefore, these studies confirm what has been already stated by the WCN research focusing on the maritime sector: advanced logistics is not exclusively located in transport hubs but is also found in specialized and knowledge-intensive contexts (World Cities).

Unlike the studies related to the maritime sector, the research on logistics in the WCN perspective is scant. Antoine et al. (2017) developed an interlocking network approach at the national level to analyses the Italian advanced logistics network in 2013 and found that the Italian advanced logistics appears to be primarily attracted by knowledge-rich environments, rather than infrastructural nodes. The Italian network is agglomerated in the world city of Milan, which acts as a hub, while part of the information and power are distributed in some secondary cities, depending on their sectorial and geographical specificities.

The present study contributes to an understanding of the issues raised in this literature by presenting an interlocking network for advanced logistics in Europe, which makes it possible to measure the Logistics Global Network Connectivity of European cities, and also identify determinants of this outcome.

\section{Data and Methodology}

This section describes the data that have been utilized in the research.

The selection of the logistics companies is based on the list of 62 global leading 3PL firms proposed by O'Connor et al. (2016). This selection will ensure a continuity in the debate on the logistic city networks (Figure 1). Nevertheless, since the focus is on the European countries, the final list was limited to firms owning 5 or more offices in Europe, which reduces the sample to 27 companies (see appendix 1), 13 of which are based outside Europe 4 . These companies own 722 offices, which are located in 140 cities $^{5}$. As logistics firms have the twin functions of managerial/high-level activities and operating functions that requires large spaces and convenient access to infrastructures (Mariotti, 2015) the commonly choose locations in urban peripheries or close to ports and airport (Hesse, 2008; Verhetsel et al., 2015; Holl \& Mariotti, 2017) rather than the central business districts (CBD).By aggregating the offices of the same company located in a given city, 461 city-office pairs have been defined (Figure 1).

The Amadeus database ${ }^{6}$, developed by Bureau Van Dijk, has been used as the main data source for the construction of the interlocking network together with the official website of each firm. While Taylor et al. (2002) demonstrated that firm web sites are valid data sources for the analysis of the APS, this data source is questionable in the case of 3PL due to their twin functions Part of the establishments that have been found in the websites (e.g. warehouses, etc.) are not relevant for the purpose of the analysis. Besides, 
in some cases, it is difficult to distinguish between purely operational locations and offices that perform advanced services. For this reason, the present study is based on the Amadeus database, which is limited to head offices (a proxy of the high value informational activities).

The Amadeus database provides location information at city level only for national headquarters and national division headquarters of the selected company and their subsidiaries ${ }^{7}$.

The surveyed companies have, in most cases, several divisions that are often registered independently 8 . Here, the term 'division' refers to the company business sector. Similar to other large companies, in the logistics service providers, commercial functions (marketing, customer services, etc.) are distinguished from support activities (e.g. IT,

HR). "These divisions have their own localization requirements and can be located at the headquarter or elsewhere. A general framework has been developed (Luthi et al. 2013), representing a simplified value chain of companies" (Antoine et al, 2017, p. 756). One can assume that the importance of a city in a given corporate network is related to the number of division offices it hosts. By aggregating the offices of the same company located in a given city, 461 city-office pairs have been defined. The information provided by the Amadeus database does not allow distinguishing the regional or global head offices of the selected companies or the offices with special command functions.

The area of enquiry has been determined based on the different levels of the countries' political and economic integration (i.e. the overlap of the Schengen area and European Union, cfr. grey area in Fig. 2).

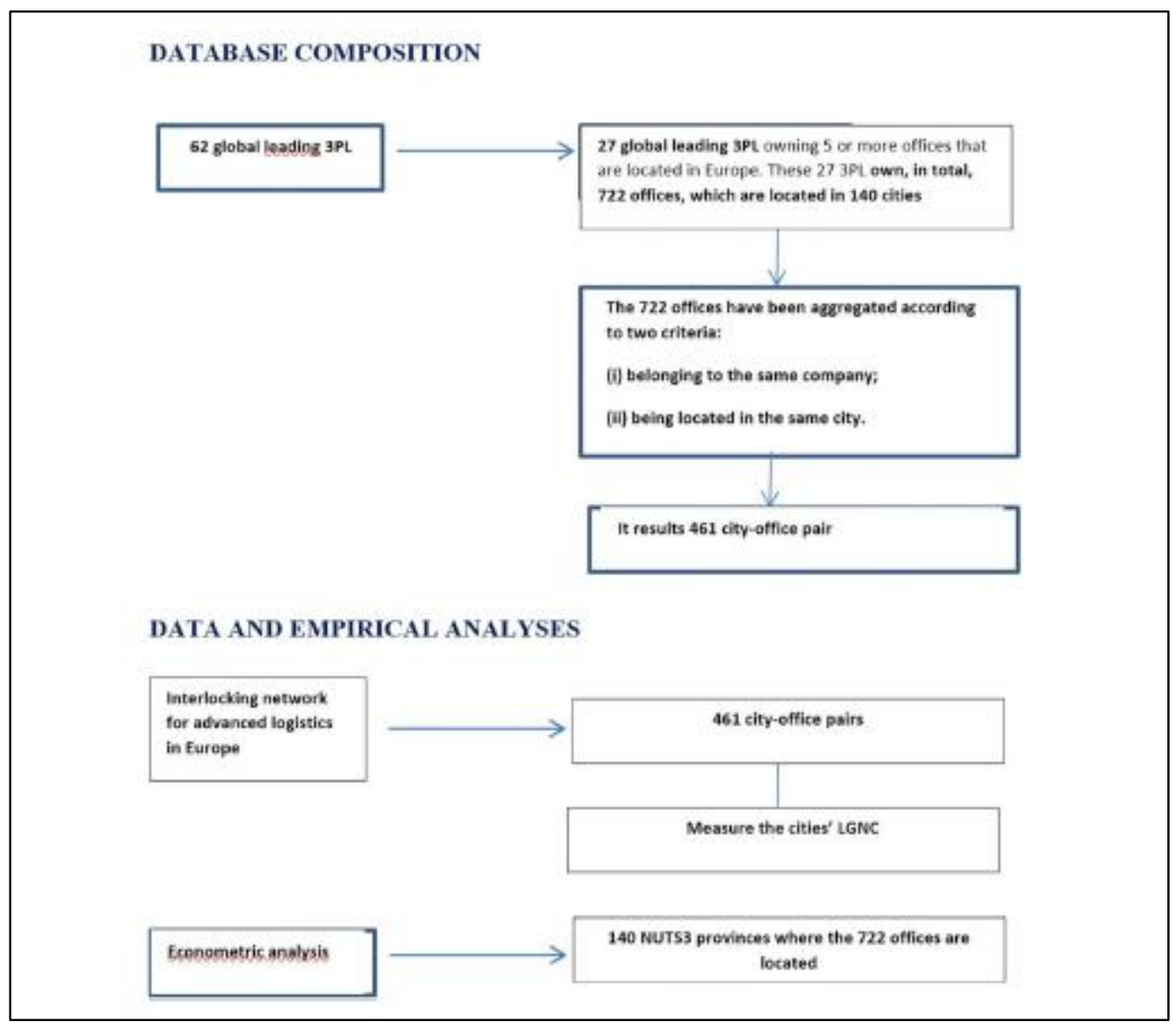

Fig 1: Data composition and empirical analyses

Source: Authors' elaboration on O'Connor et al. (2016), Amadeus database and firms' web sites. 
As presented in Figure 1, the interlocking network for advanced logistics in Europe is based initially upon the 461 city-office pairs, and can be used to measure the LGNC of the host cities, utilizing the Taylor $(2001,2004$, 2007) methodology.

Based on this method, every city-office pair (i.e. 461) is given a score within a predefined range, according to the importance of the performed functions. For example, the score, called "service value", for the office of the $j$ company in the $i$ city $\left(v_{i j}\right)$ will be zero if the company does not have an office in this city; equal to 1,2 and 3 if it has a minor, a standard or a major office, respectively; equal to 4 for a regional headquarter, and equal to 5 for the global headquarter. It is worth underlining the fact that the attribution of these values is subjective, since we are dealing with a qualitative methodology. In our analysis, the scores have been assigned as follows: global head office (only European companies): 5 points; regional head office (Europe or parts of Europe e.g. Kuehne+Nagel East Europe): 4 points (maximum score for non- European companies); division (market/sector-specific) global head office (e.g., Logwin international solution) and cities with 5 or more national division head office (without supranational functions): 3 points; cities with 3 or 4 national division head office: 2 points; cities with 1 or 2 national division head office: 1 point. It should be noted that for the non-European companies the maximum service value is equal to 4 , or even lower for those nonEuropean companies that have not registered a regional head office in Europe. Once the presence and importance of the considered offices is defined, the methodology proceeds to quantify the relationship between offices pairs. With reference to intra-firm relations, it is assumed that larger offices have more relationships with other offices than smaller ones (one branch office will have numerous contacts with the headquarter, and little contact with other branch offices). The elemental interlock link $r_{a b, j}$ between cities $a$ and $b$ with regards to firm $j$ is defined by:

$$
r_{a b, j}=v_{a j} * v_{b j}
$$

The aggregate city interlock link $r_{a b}$ between cities $a$ and $b$ is then obtained summing the intra-firms links of all investigated firms:

$$
r_{a b}=\sum_{j} r a b_{1} j
$$

For each city there are n-1 such links, i.e. links toward each other city. The internal relatedness or selfrelation $r_{a}$, that express the importance of the offices present in a city, is instead expressed as follow:

$$
r_{a}=\sum_{j} v_{j a}^{2}
$$

The connection between two cities can also be expressed in proportional terms i.e. as a proportion of the maximum possible linkage $\mathrm{H}$ :

$$
\mathrm{H}=\sum_{\mathrm{j}} \mathrm{h}_{\mathrm{j}}^{2}
$$

Where $h_{j}$ is the highest service value provided by firm $j$ across all cities. The proportional city interlink $P_{a b}$ between cities $a$ an $b$ (used in Table 2) is then obtained as follow:

$$
P_{a b}=r_{a b} / H
$$

Eventually, the nodal connection of city $a$, that gives its positioning in the ranking of the World City Network, is obtained by summing its city interlock links with every other $i$ cities within the network:

$$
N_{a}=\sum_{i} r_{a i} \quad a \neq i
$$


In the rest of the paper, building on the GNC acronym used in WCN literature, we refer to the positioning of cities within the European Logistic Network with the acronym LGNC (ie Logistic Global Network Connectivity) that corresponds to $N_{i}$.

Given the sum of the nodal connection of all cities $i$, that is defined as total network interlock linkage $(T)$ :

$$
T=\sum_{i} N_{i}
$$

The situational status of a city can also be expressed - as in Table 1 - as a proportion of T:

$$
L_{a}=\left(N_{a} / T\right)
$$

A city nodal connection value is de facto related to the following factors: a) number of firms; b) importance of local offices (service value); c) offices belonging to firms with a large network.

\section{Analysis and Discussion of the Interlocking Network Model}

The analysis of the European advanced logistics Interlocking Network Model considers a large number of European cities (140 in total), since all cities hosting at least one national division head office of 3PL are taken into account. The values concerning number of offices, service value and gross connectivity vary among the cities. As concerns the offices distribution, while eight cities host offices of more than half of the considered firms (with a maximum value in Milan, which hosts $70 \%$ of surveyed companies ${ }^{10}$ ), 91 cities (60\% of the sample) feature a single company. The size of intra-firm networks vary widely, too. The most developed network is the one by DHL with 39 cities, while Wincanton is located only in three cities ${ }^{11}$. This difference is in part explained by each firm's specific localization strategies (centralization or diffusion of managerial functions), or by its size: even if all firms enter the top 60 leading global 3PL, there are strong differences in terms of turnover.

The map in Figure 2 depicts the Logistics Global Network Connectivity (LGNC) of the top 19 European logistics cities, aggregated by classes. For $\alpha$ and $\beta$ categories, the size of the circles is proportional to the LGNC value. About $50 \%$ of the total connectivity is distributed among the top 19 cities ( $\alpha$ and $\beta$ categories). Paris clearly stands out in the network with a connectivity level that is $50 \%$ higher than the second city (London).

The center of gravity of the European advanced logistics is located in the North West. The presence of high ranked cities in this area is both related to the concentration of offices, and of the majority of headquarters (see Table 1). Southern Europe is virtually absent from the map, except for the two major centres: Milan and Madrid. Finally, Central and Eastern Europe is quite well represented, especially if compared to its demographic weight. Nonetheless, with approximately one city per country in the $\alpha$ and $\beta$ categories, we observe the influence of the national city hierarchy on the results This result though, is magnified by the characteristics of the data source which utilizes national headquarters). Fig 2 outlines a rather strong position of Antwerp in comparison with Rotterdam or Hamburg. With reference to Antwerp, localization choices within Belgium create a huge national advantage for that city.

On the contrary the ports of Rotterdam and Hamburg have a relatively low position in the ranking because in their national context there are other attractive cities for the APS influence upon the location of the 3PL firms. Examples are Amsterdam and Frankfurt, which are not only world-class cities in the a class of GaWC, but they also host numerous 3PL headquarters, which represent a pull factor for other 3PL firms creating a $3 \mathrm{PL}$ cluster). Vice versa, Antwerp, despite the lower traffic, ranks as first port-city since its national competitor "Brussels" appears less attractive for logistics operations. Hence, in Belgium the port-city is the 
preferred location with respect to the world city.

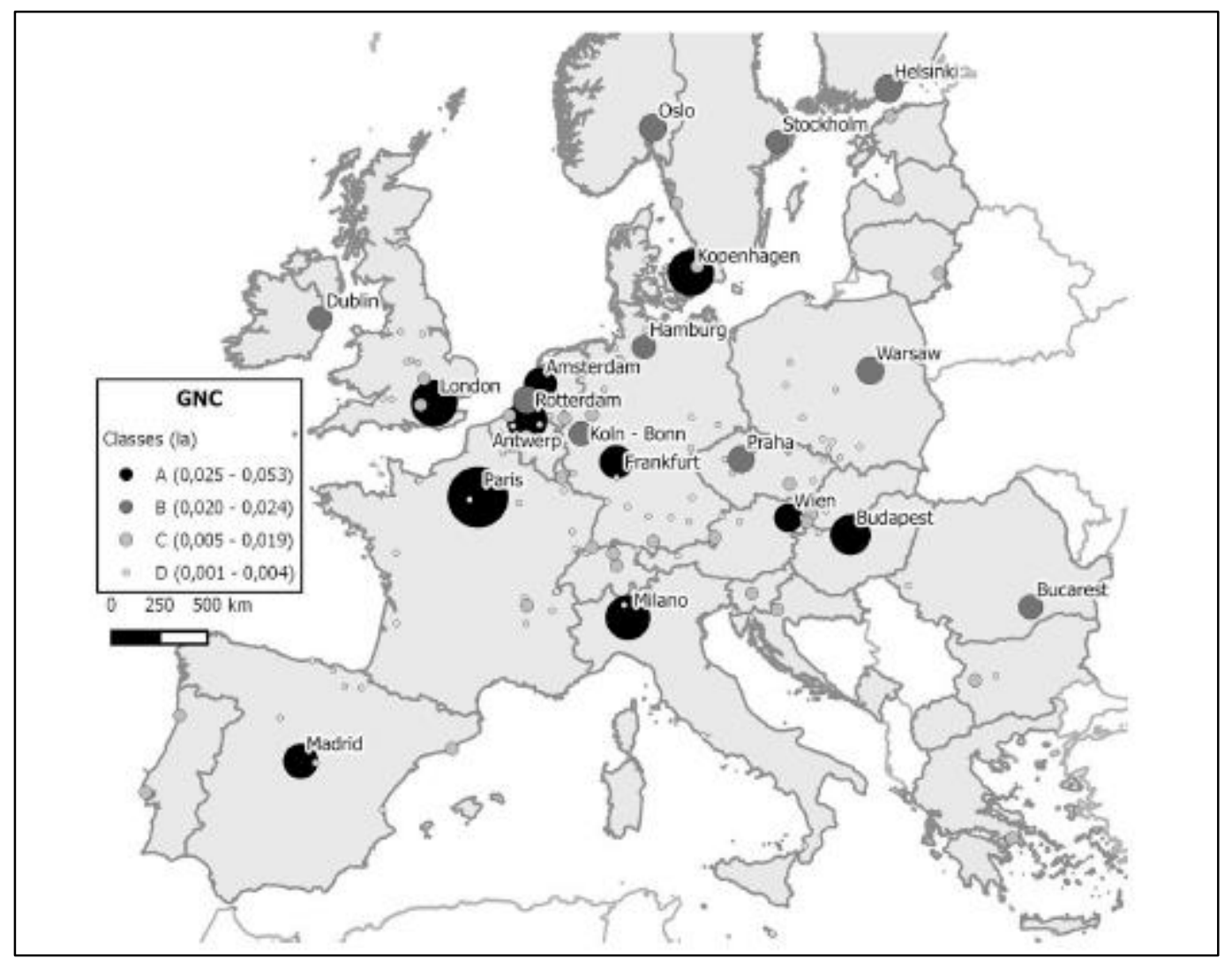

Fig 2: Logistics Global Network Connectivity of the top 19 European logistics cities, aggregated by classes

Source: Authors' elaboration

Beside connectivity levels, the analysis defines the relevance of the links connecting the most important cities. Figure 3 focuses on class $\alpha$ cities, where the color and size of the circles refer to internal relatedness $r_{a}$ rather than global connectivity. Internal relatedness expresses, above all, the presence of important offices. Amsterdam is an example of city with high internal relatedness (second) if compared to its ranking with regard to the connectivity to other cities (ninth). Specifically, it hosts 4 global/regional headquarters, but some of them have a poorly developed intra-firm network, and, therefore, have a weak influence on the city's global connectivity level . 


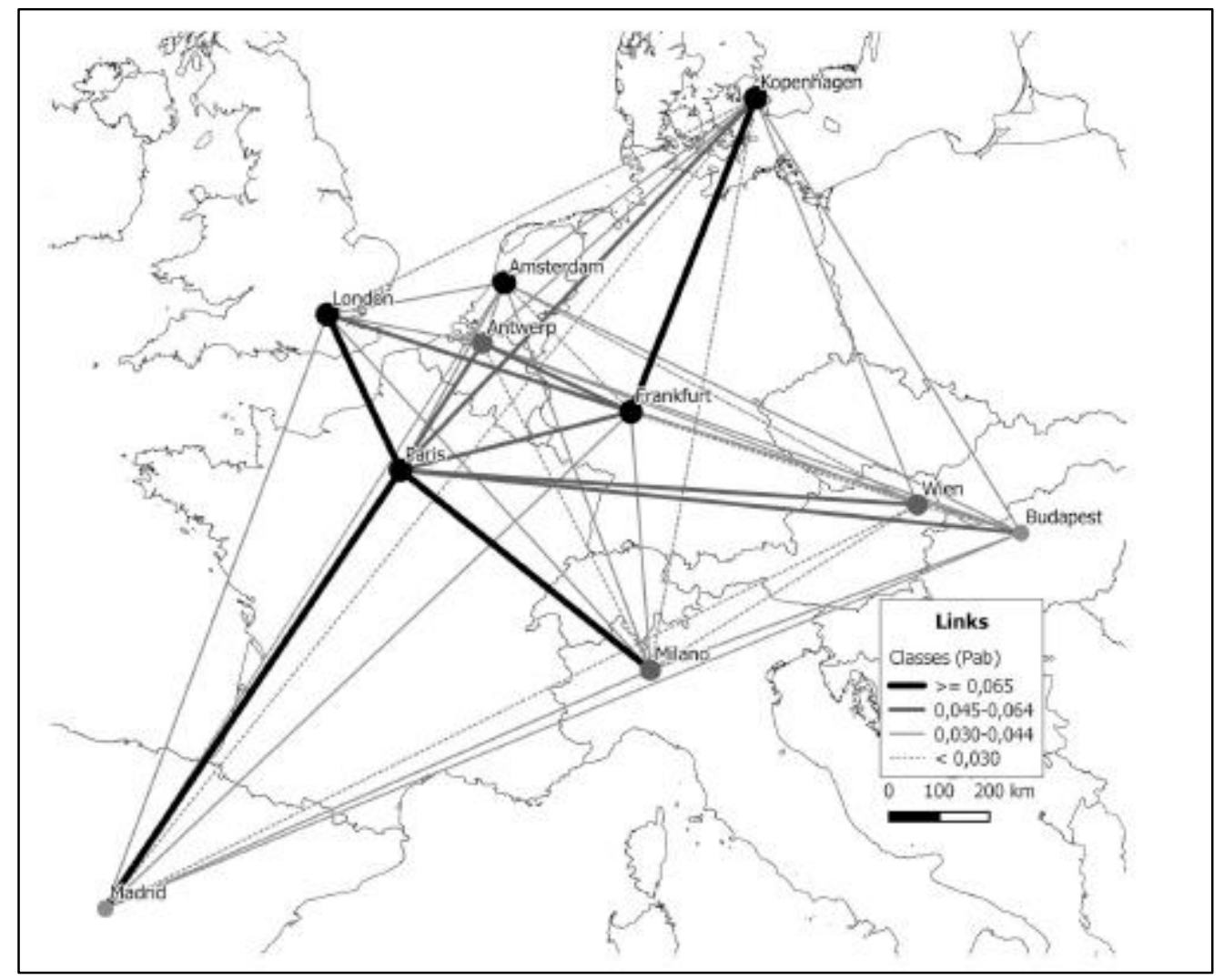

Fig. 3: Network of the first ten European Logistics Cities.

Note: The color and size of the circles refer to internal relatedness rather than global connectivity. The internal relatedness for city expresses above all the presence of important offices.

Source: Authors' elaboration

Figure 3 reflects the dominant position of Paris, already highlighted in the connectivity map. In fact, as concerns class $\alpha$ cities, most of the links, belonging to the two upper classes, involve Paris. The links from those classes, which do not involve Paris, connect cities that host global/regional headquarters.

In order to introduce the understanding of the locational determinants that will be discussed in the next section Table 1 shows the $19 \alpha$ and $\beta$ cities with reference to their positioning within the network (connectivity rank and class), and the presence of headquarters of the analyzed firms, and the presence of important transport hubs (main freight ports and airports). 
Table 1: Characteristics of the top 19 logistics cities with regards to their position in the WCN and the presence of $3 P L$ headquarters, ports and airports

\begin{tabular}{|c|c|c|c|c|c|c|}
\hline Connectivity rank, (class) & N. flrms & Clty (country) & WCN, 2012 & N. HQ/RHQ & Top 10 European ports (tons or TEU) & Top 10 European fredght alport \\
\hline 1 (a) & 16 & Parts (FR) & $a+$ & 3 & & $\mathbf{x}$ \\
\hline $2(a)$ & 18 & London (UK) & $a++$ & 1 & & $\mathrm{x}$ \\
\hline 3 (a) & 9 & Copenhagen (DK) & $\beta+$ & 1 & & \\
\hline $4(a)$ & 10 & Mllano (rr) & $a$ & & & $\mathrm{x}$ \\
\hline $5(a)$ & 16 & Antwerp (BE) & $\beta$. & 1 & $x$ & \\
\hline $6(a)$ & 17 & Budapest (HU) & $\dot{\beta}+$ & & & \\
\hline $7(a)$ & 14 & Madrid (ES) & $a$ & & & \\
\hline $8(a)$ & 14 & Prankfurt AM (DE) & $a$ & 3 & & $\mathrm{x}$ \\
\hline $9(a)$ & 14 & Amsterdam (NL) & $a$ & 4 & $x$ & $\mathrm{x}$ \\
\hline $10(a)$ & 9 & When (AT) & a. & 1 & & \\
\hline $11(\beta)$ & 9 & Helstnka ( $\mathrm{FI})$ & $\beta$ & & & \\
\hline $12(\beta)$ & 9 & Oslo (NO) & $\beta$ & & & \\
\hline $13(\beta)$ & 9 & Rotterdam (NL) & $\beta-$ & 1 & $x$ & \\
\hline $14(\beta)$ & 12 & Warsas (PL) & a. & & & \\
\hline $15(\beta)$ & 13 & Praha $(C \not)$ & a. & & & \\
\hline $16(\beta)$ & 11 & Bucaresth (no) & $\beta+$ & & & \\
\hline $17(\mathrm{p})$ & 12 & Dublin (IE) & a. & & & \\
\hline $18(\beta)$ & 6 & Hamburg (DE) & $\beta+$ & 2 & $x$ & \\
\hline $19(\beta)$ & 9 & Stadkholm (SE) & a. & & & \\
\hline
\end{tabular}

Source: Gawe (2012) and Eurostat.

- The ranking is based on the calculated LGNC

This summary table confirms the WCN literature on ports and logistics, highlighting locational preferences toward knowledge-intensive environments. 3PL firms tend to concentrate their management functions in world cities characterized by urbanization economies or in a cluster of transport related industries where they can exploit localization economies. Regarding the latter, it seems that managerial functions seek proximity to other related skilled and high-level functions. This kind of specialized environment can be found not only near transport hubs (that often hold both operational and informational functions), but also in centers characterized by the concentration of headquarters and clusters of specialized firms from both the logistics sector and other transport related industry (e.g. Copenhagen, Oslo). Table 1 shows how most connected cities are often characterized by the presence of both general and specialized knowledge. As concerns the last statement, it is however interesting to reflect on the positioning of a city such as Milan, that is particularly well ranked (4 ${ }^{\text {th }}$ position), despite a lack of general headquarters and important transport functions like a port. In this regard, it must be remembered that the concept of city connectivity goes beyond the presence of important offices/command centers (Kleiber, 2017). In fact, it rests on the competitive advantages deriving from interaction, i.e. relationships between different firms located in the same city and in other cities thanks to intra-firm network of offices. Milan is apparently considered by 3PL firms "a place to be" (in fact it has the highest number of offices), because it is the most important World City in Southern Europe, and it is the economic and financial center of Italy. Moreover, even if Milan is not a typical global logistics command center (no global headquarters, no tradition in the transport sector), it is a highly competitive location for regional/national governance because of the amount of information that circulates in the city thanks to the co-presence of representatives of almost all leading 3PL firms as well as leading firms from other sectors (insurance, finance, etc.) (Mariotti, 2018).

\section{Empirical analysis on the determinants of the European LGNC}

The econometric analysis outlined below is, developed to explore the variables explaining the cities' LGNC at the NUTS3 province level, which provides data for descriptive statistics and econometric analysis (Ordinary Least Square - OLS) of the LGNC of 140 European cities (Figure 1).

Empirical studies suggest that a city's LGNC can be favored by: (i) agglomeration economies; (ii) physical accessibility; (iii) non-physical accessibility (network economies); (iv) innovation activity. Specifically, agglomeration economies, which enable knowledge spillover between individuals, can be proxied by GDP per capita, and freight as a share of GDP, in order to control the economic size and the freight flows. Physical accessibility is proxied by the location of ports and airports, which boost economic performance, and also by the freights share of GDP. 
As several authors have outlined (Bentlage et al., 2013; Button \& Taylor, 2000, Goebel et al., 2007), airports attract knowledge-intensive firms, which in return drive spatial development. These firms need diverse labor skills, which are mainly found in large agglomerations, along with airports and ports that offer good access to global markets. Besides, since there is an interplay between the physical movement of people and the non-physical exchange of information, it is important to consider the non-physical accessibility, which is represented by intra-firm network. As Bentlage et al. $(2013,48)$ has observed "Network economies highlight the effects of strategic links between hubs of knowledge" and these economies can be proxied by the e GaWC ranking. Finally, the degree of innovative activities is provided by the number of patents registered by firms in the NUTS3 level region. As part of the research, the concept of urbanization economy refers specifically to the urbanization externalities typical of world cities, as opposed to the localization externalities characterizing ports / logistic nodes. In this perspective, the proposed methodology tries to assess urbanization economies, which are proxied by the variable identifying the city score in the GaWC ranking.

The following analysis explores the role of the above-mentioned explanatory variables in shaping each city's LGNC score. (Table 2). While LGNC is measured for the year 2014, the explanatory variables are considered for the years 2012 or 2013 (depending on the data availability).

Table 2: Variables description

\begin{tabular}{|c|c|c|}
\hline \multicolumn{3}{|c|}{ Dependent vartable } \\
\hline LGNC: & Logetedtc Nenwark Connectity in 2014 (ctiy level) & Amadaus datnbese, finss webstins \\
\hline GDP & CDP per capita at NUTS3 leved in 2013 (ln) & Eurostat \\
\hline Frelght-GDP & Volume of frelght transport relattive to GDP in 2013 at NUTS3 level (In) & Eurostat \\
\hline Port & Dummy varlabile taking value 1 to the dity hosts a port, 0 otherwise in 2013 (In) & OpenStreetMap \\
\hline Alrport & Dummy varlable taking value 1 tif the ctity hosts an atrport, 0 atherwise in 2013 (ln) & OpenStreetMap \\
\hline Patents & Number of patents at NUIS3 kevel in, 2012 (In) & Eurostat \\
\hline
\end{tabular}

Table 3: Descriptive statistics

\begin{tabular}{llllll}
\hline Vartable & Obs. & Mean & Std.dev. & Min & Mix \\
\hline LCNC2014 & 140 & 124.3857 & 160.9824 & 10 & 922 \\
GDPcap13 & 140 & 0.0401219 & 0.347957 & 0.0066419 & 0.3363071 \\
Pat12 & 136 & 106.1426 & 0.0347957 & 0.2 & 1061.68 \\
ProDP13 & 140 & 91.24357 & 19.74504 & 47.2 & 146.7 \\
Port & 140 & 0.3071429 & 0.4629656 & 0 & 1 \\
Airport & 140 & 0.7428571 & 0.4386282 & 0 & 1 \\
WNC2012 & 140 & 0.6785714 & 1.087984 & 0 & 4 \\
\hline
\end{tabular}

The dependent variable LGNC shows a rather high standard deviation, having an average value of about 124, the same holds for patents (Table 3). The explanatory variables: GDP per capita and number of patents are correlated at $57.4 \%$, therefore they are not included in the same model (Table 4). 


\begin{tabular}{|c|c|c|c|c|}
\hline & \multicolumn{4}{|c|}{ LILENC 2014} \\
\hline & (1) & (2) & (3) & (4) \\
\hline InGDPCAP13 & $7.140_{\text {nes. }}$ & $6.253 \ldots$ & & \\
\hline Inpat12 & & & 0.012 a. & $0.101_{\text {as }}$ \\
\hline InFFCDP13 & 0.2200 & 0.252 & 0.312 & 0.322 \\
\hline Purt & 0.387 a.. & 0.450 a... & 0.357 an. & 0.413 . \\
\hline Atr & 0.359 .... & $0.382_{\text {nas. }}$ & $0.352_{\text {as }}$ & $0.375_{\text {ma. }}$ \\
\hline WCN2012 $\beta / 1$ & $0.464=$ & $0.524_{\text {as }}$ & 0.339 & 0.417 \\
\hline WCN2012 $a$ and $a-/ 2$ & $0.946 \ldots$ & $0.963 \ldots$ & 0.930 as. & $0.941_{\text {as. }}$ \\
\hline wCN2012 $\alpha++$ and $\alpha+/ 3$ & 1.912 a.t. & $1.963 \ldots$ & 1.840 an: & 1.897 a.s. \\
\hline WCN2012/4 & $1.4200_{n}$ & $1.520 \mathrm{~m}$ & $2.443 \ldots$ & 2.381 .... \\
\hline Dummy macro area & NO & YES & NO & rEs \\
\hline cons & 2.116 & 1.951 & 1.576 & 1.538 \\
\hline Ohs. & 140 & 140 & 136 & 136 \\
\hline Radj & 0.4933 & $0.49 \mathrm{n}$ & 0.4776 & 0.4823 \\
\hline Prob. & 0.0000 & 0.0000 & 0.0000 & 0.0000 \\
\hline
\end{tabular}

Table 4 presents the OLS estimates, including, in model (1): GDP per capita, freights share of GDP, WCN rank, and control variables for transport accessibility (port and airport), and in model (2) the previous variables plus the geographical fixed effects (macro areas).

Models 3 and 4 differ from models 1 and 2 because the variable GDP per capita is substituted by the variable Patents, being the two variables correlated.

As expected, the study highlights that cities having a high LGNC show a high GDP per capita, and register a high number of patents. They tend to host a port and/or an airport and have a higher WCN: respectively WCN 4 (are $\alpha++$ and $\alpha+$ cities) and WCN 3 (consists of $\alpha$ and $\alpha$ - cities).

It is very important to underline that, by contrast, freight flows relative to GDP seem not to influence the cities' GNC. These results might be explained by the fact that transport hubs (ports and airports), because of their peculiarity to be specialized knowledge centers, have a strong impact on the cities' LGNC. This may occur because they attract 3PL firm management functions, whereas logistics operational intensive functions, which are mainly low added-value, are accommodated in areas characterized by huge transport flows (Holl \& Mariotti, 2017). The relevance of knowledge intensive areas for cities' LGNC is also corroborated by the significance of patents and of WCN. Cities' Connectivity is, therefore, reinforced by transport accessibility due to clusters of specialized knowledge associated with ports and airports, and it is more relevant for cities belonging to the high World City Network (category, and therefore with a higher GDP.

\section{Conclusion and policy implication}

The present study has developed an interlocking network for advanced logistics in Europe, measured the cities' LGNC, and its main determinants. The mixed methodological approach, based on an interlocking network and an econometric analysis, fills the gap in the literature about advanced logistics from a WCN perspective. Besides, the study provides the first interlocking network applied to the logistics sector, overcoming specific constrains related to data collection on advanced logistics.

To reach this goal, the interlocking network model by WCN has been enriched through accessing the Amadeus database. This data source allows selecting location-based information at city level about national head offices and national division head offices, therefore distinguishing the low-level functions (e.g. purely 
operational locations such as freight transport and handling) from the high-level ones (e.g. offices that perform advanced services). Another advantage offered by Amadeus concerns the qualitative information about companies, which allows one to focus on the analysis at the divisions level, thus assessing the positioning of the cities, and the relationship between cities at the European level.

The results show that about $50 \%$ of the total connectivity between firms in logistics is distributed among the top 19 cities ( $\alpha$ and $\beta$ categories), with Paris outstanding in the network. The center of gravity of advanced logistics in Europe is in the North West; the presence of high ranked cities in this area is related to its concentration of offices and the majority of 3PL firm headquarters. Southern Europe is virtually absent from the map while Central and Eastern Europe is rather well represented. Considering the ongoing shift of logistics and distribution of activities towards Central and Eastern Europe, the most plausible hypothesis for the future of this region is a scenario characterized by a few main centers acquiring importance as "intermediate node", as it may be the case of Budapest. These cities probably will not be hosting corporate headquarters but will be the places where the Central and Eastern Europe's national / regional offices of almost all $3 \mathrm{PL}$ will concentrate.

This scenario is similar to what is already happening in Southern Europe as in the Italian case of Milan. This city does not attract the 3PL headquarters but hosts the regional headquarters of a very large number of these firms. This specific phenomenon, mainly linked to localization economies, explains the high score of the city in the LGNC ranking even in the absence of global headquarters.

The empirical findings regarding the interlocking network analysis reveal that 3PL management functions (that generate logistics connectivity) are attracted by: a) World Cities as knowledge-rich environments and connected places, and characterized by urbanization economies, and b) port and airport infrastructures as clusters of specialized knowledge (transport and logistics industry), where localization economies can be exploited. Indeed, the results highlight that first ranked physical freight cities do not necessarily correspond to logistics «command and control centers».

As for the determinants of the LGNC, the results corroborate the key role played by the World City Network ranking (especially $\alpha$ cities). Moreover, the analysis highlights the importance of the economic (GDP) and innovation (patents) performance at city level, and the location of transport hub(s). On the other hand, freight flows relative to GDP is not an influential factor on the LGNC of cities. In this perspective, infrastructural nodes, per se, lose importance given firms' locational preferences for the location of their management functions. Furthermore, the presence of infrastructure may be relevant for a city to be at least 'ranked', but it is not sufficient to attract the most important functions. In other words, the effects of the location pattern of operational logistics, on one hand, and that of advanced logistics services, on the other are different.

Overall, study's use of a specific methodological approach - logistics interlocking network supported by the econometric analysis - has extended our understanding of the part logistics plays in shaping the WCN. Based on the results, we may also identify policy implications. These could point to actions needed by cities facing some of the negative effects of logistics transformations, such as negative externalities linked to traffic and to the growth of low-skilled labor. In such a context, the research suggests the priority would be to focus on the development of specialized knowledge in order to develop advanced functions. In some cases, this may involve working in collaboration with the nearest higher-ranked world city to create or develop potential synergies. One example could be the potential evolution of a relationship between Genoa and Milan.

\section{Funding}

The author(s) received no financial support for the research, authorship, and/or publication of this article. 


\section{Notes}

1 See http://www.lboro.ac.uk/gawc/gawcworlds.html, for the WCN ranking in 2000; 2004; 2008; 2010; 2012; 2016 and detailed references.

2 4PLs offer a larger number of high value-added services (i.e. transport, storage, inventory management, tracking and tracing, packaging, labelling and secondary assembly of products) (Brewer et al., 2001; Elia et al., 2011).

3 Data are at global level and refer to 2013.

4 In 2015 XPO acquired Norbert Dentressangle. While in the Amadeus database they were still recorded separately, we aggregated them. Even if the XPO global head quarter is based in the US, we considered it as a European firm, with a 5-point service value in Lyon, because the network and importance of offices still reflect the characteristics of Norbert Dentressangle before the acquisition.

5 Originally, the cities were 144, however, since the econometric analysis is run at NUTS3 level, when two cities belonged to the same NUTS3 province, the less important one has been dropped, thus obtaining 140 observations.

6 The Amadeus database contains information on about 21 million companies across Europe (https://www.bvdinfo.com/en-us/our-products/company- information/internationalproducts/amadeus)

7 The national headquarter is the head office of the affiliate (Foreign Direct Investment- FDI), the foreign multinational firm has opened in a host country, while a national division headquarter is related to the business sector of the firm.

8 As an example, in Basel there are 2 divisions for Agility Switzerland: Agility Logistics Management and Agility.

9 For La and Pab in Fig 1 and 2, see formula (cf. Taylor, 2001).

10 Italy attracts transport and logistics foreign direct investment thanks to its strategic position in Southern Europe, and because it represents a "market" where to invest since its transport and logistics industry is small sized and mainly specialised in low value- added sectors.

11 The small size of Wincaton network of offices across Europe is related to this business mostly focused on UK and Ireland.

\section{References}

Antoine S., Sillig C. \& Ghiara H. (2017). Advanced Logistics in Italy: A City Network Analysis. Tijdschrift voor economische en sociale geografie 108 (6), 753-757.

Beaverstock J.V., Smith R.G. \& Taylor P.J. (1999). A roster of World Cities. Cities 16, 445-458.

Bentlage M., Lüthi S. \& Thierstein A. (2013). Knowledge creation in German agglomerations and accessibility - An approach involving non-physical connectivity, Cities. Elsevier Ltd, 30(1), 47-58.

Brewer A.M., Button K.J. \& Hensher D.A. (2001). Handbook of Logisitcs and Supply Chain Management. Amsterdam: Pergamon 
Derudder B., Taylor P.J. \& Witlox F. (2007). Les villes dans les reseaux mondiaux : Une nouvelle méthodologie pour cartographier la position relationelle des villes Revue d'Economie Régionale et Urbaine 2007(2), 179-200.

Elia S., Maggi E. \& Mariotti I. (2011). Does the transport industry gain from manufacturing internationalization? An empirical investigation on the Italian regions, European Transport- Trasporti Europei, vol. 49, Dicembre, 1-22, ISSN 1825-3997.

European Commission (2011), Roadmap to a single European transport area - Towards a competitive and resource efficient transport system. White Paper, in-cluding the Impact Assessment, Brussells.

GaWC (Globalization And World Cities Research Network) (2012) The World According to GaWC 2012. Available at: www.lboro.ac.uk/gawc/world2012t.html (accessed 12 December 2017).

Goebel V., Thierstein A. \& Luthi S. (2007). Funtional Polycentricity in the megacity region of Munich, Association of European Schools of Planning (AESOP), July 2007, Napoli (IT).

Graham L. \& Sahling L. (2004). European Warehouse Market Research. Overview of Pan European Trends. Amsterdam: Prologis.

Growe A. \& Blotevogel H. (2011). Knowledge Hubs in the German Urban System: Identifying Hubs by Combining Networking and Territorial Perspectives Raumforschung und Raumordnung 69, 175-185.

Hall P.V., Jacobs W. \& Koster H. (2011). Port, Corridor, Gateway and Chain. Exploring the geography of advanced maritime producer services. In: Hall P.V., McCalla R., Comtois C. \& Slack B. (eds) Integrating Seaports and Trade Corridors. Farnham- Burlington: Ashgate, pp. 81-100.

Hall P.V. \& Hesse M. (2013). Cities, regions and flows, Routledge studies in human geography. London; New York: Routledge.

Hesse M. (2008). The city as a terminal: the urban context of logistics and freight transport. Farnham- Burlington: Ashgate.

Hesse M. (2013). Cities and flows: Re-asserting a relationship as fundamental as it is delicate. Journal of Transport Geography 29, pp. 33-42.

Hesse M. \& Rodrigue J.-P. (2004). The transport geography of logistics and logistics distribution", Journal of Transport geography 12, pp. 171-184.

Hesse M. \& Rodrigue J.-P. (2006). Global Production Networks and the Role of Logistics and Transportation. Growth and Change 37, pp. 499-509.

Holl A., Mariotti I. (2017). The geography of logistics firm location: the role of accessibility, Networks and Spatial Economics, On line first, DOI 10.1007/s11067-017- 9347-0, pp.1-25.

Jacobs W., Ducruet C. \& De Langen P. (2010). Integrating world cities into production networks: the case of port cities. Global Networks 10. pp. 92-113.

Jacobs W., Koster H. \& Hall P. (2011). The Location and Global Network Structure of Maritime Advanced Producer Services. Urban Studies 48, pp. 2749-2769.

Kleibert J. (2017). On the global city map, but not in command? Probing Manila's position in the World City Network. Environment and Planning A 49(12), 2897-2915.

Laarhoven V.P., Berglund M. \& Peters M. (2000). "Third-party logistics in Europe - five years later." International Journal of Physical Distribution \& Logistics Management, 30 (5), pp. 425-442.

Lüthi S., Thierstein A. \& Goebel V. (2010). Intra-firm and extra-firm linkages in the knowledge economy: The case of the emerging mega-city region of Munich, Global Networks, 10(1), pp. 114-137.

Lüthi S., Thierstein A. \& Bentlage M. (2013). The Relational Geography of the Knowledge Economy in Germany: On Functional Urban Hierarchies and Localised Value Chain Systems, Urban Studies, 50(2), pp. 
276-293

Lüthi S., Thierstein A. \& Hoyler M. (2018). The world city network: Evaluating top-down versus bottom-up approaches, Cities. Elsevier, 72, pp. 287-294.

Maggi E., Mariotti I. (2010), "Logistics FDI in Italy: integration strategies and motivations", European Transport Research Review, (2): 1, 13-24.

Mariotti S., Mutinelli M. \& Piscitello L. (2003). Home country employment and foreign direct investment: evidence from the Italian case. Cambridge Journal of Economics 27, pp. 419-431.

Mariotti I. (2015). Transport and logistics in a globalizing world. A focus on Italy, Springer, Heidelberg-New York.

Mariotti I. (2018). The attractiveness of Milan and the spatial patterns of international firms. In S. Armondi \& S. Di Vita (eds.), Milan: Productions, Spatial Patterns and Urban Change (pp. 48-59). Routledge: London-New York.

Norall S. (2013). 3PL vs 4PL: What are these PLs anyway? Layers of logistics explained. Available at: http://cerasis.com/2013/08/08/3pl-vs-4pl/ (accessed 12 December 2017).

O'Connor K. (2010). Global City regions and the location of logistics activity. Journal of Transport Geography 18. pp. 354-162.

O'Connor K., Holly B. \& Clarke A. (2012). A case for incorporating logistics services in urban and regional policy: some insights from US metropolitan areas. Regional Science Policy and Practice 4, pp.165-177.

O'Connor K., Derudder B. \& Witlox F. (2016). Logistics Services: Global functions and global cities. Growth and Change 47(4), pp. 481-496

Pain K. \& Hall P. (2006). The Polycentric Metropolis. Learning from Mega-city Regions in Europe. Oxford: Earthscan.

Razzaque M. \& Sheng C. (1998). Outsourcing of logistics functions: a literature survey. International Journal of Physical Distribution \& Logistics Management 28, pp. 89-107.

Rodrigue J.-P. (2006). Challenging the derived transport-demand thesis: geographical issues in freight distribution. Environment and Planning A 38, pp. 1449-1462.

Saglietto L. (2013). Toward a classification of fourth party logistics (4PL). Universal Journal of Industrial and Business Management 1(3), pp. 104-116.

Sassen S. (1991). The Global City. Princeton: Princeton University Press. Sassen S. (2000).

Cities in a World Economy. Thousand Oaks: Pine Forge.

Taylor P.J. (2001). Specification of the World City Network. Geographical Analysis 33, pp. 181-194.

Taylor P.J. (2004). World City Network: a global urban analysis. London, New York: Routledge.

Taylor P.J., Catalano G and Walker DRF (2002) Measurement of the World City Network.

Urban Studies 39, pp.2367-2376.

Taylor, P.J., Ni, P., Derudder, B., Hoyler, M., Huang, J., Lu, F., Pain, K., Witlox, F., Yang, X., Bassens, D. \& Shen, W. (2009), Measuring the World City Network: New Results and Developments. GaWC Research Bulletin 300, http://www.lboro.ac.uk

UNCTAD (2013), World Investment Report, United Nations, New York and Geneve.

Verhetsel A. \& Sel S. (2009). World maritime cities: From which cities do container shipping companies make decisions? Transport Policy 16, pp. 240-250. 
Verhetsel A., Kessels R., Goos P., Zijlstra T., Blomme N. \& Cant J. (2015). Location of logistics companies: a stated preference study to disentangle the impact of accessibility, Journal of Transport Geography 42, pp.10-121.

Van Den Heuvel F.P., De Langen P.W., Van Donselaar K.H., \& Fransoo J.C. (2013). Spatial concentration and location dynamics in logistics: the case of a Dutch province, Journal of Transportation Geography 28, pp. 39-48.

Wang J. \& Cheng M.C. (2010). From a hub port city to a global supply chain management center: a case study of Hong Kong. Journal of Transport Geography 18., pp.104-115. 